\title{
SCIDOC
}

\author{
International Journal of Dentistry and Oral Science (IJDOS) \\ ISSN: 2377-8075
}

\section{Stature Estimation By Four Lateral Cephalometric Parameters: Study From A Sample Of Syrian Population}

Research Article

Khalid Joma ${ }^{1}$, Ghaith Sahtout ${ }^{2 *}$, Mahmoud Abdul-Hak ${ }^{1}$, Majid A Abo Fakher ${ }^{3}$

${ }^{1}$ Department of Oral medicine, Faculty of Dental medicine, Damascus University, Syria.

${ }^{2}$ Department of Orthodontics, Faculty of Dental medicine, Damascus University, Syria.

${ }^{3}$ College of Dentistry, Al-Ayen University, ThiQar, Iraq.

\begin{abstract}
INTRODUCTION: Stature - height of a person - is one of the big four parameters that can help to identify the human remains in forensic anthropology. Many studies around the world have reported the correlation between stature and skull \& mandible dimensions.

Aim: This study was conducted to evaluate the possibility of using four parameters related to facial and mandible dimensions taken from the lateral cephalometric image as indices for estimating height in the sample of Syrian population.

Materials and Methods: The study was conducted on 150 persons ( 70 males and 80 females) of the reviewers of the Department of Orthodontics, Faculty of Dental medicine, Damascus University, with ages between 18 to 25 years old. The height of each person was measured in centimeters, and the four parameters was measured on the lateral cephalometric images obtained from the patients' review files by Digital Vernier Caliper of the company (Mitutoyo - Japan) with a $\pm 0.01 \mathrm{~mm}$ error. The data was dumped in an Excel 2013 file, and then statistically processedusing SPSS version 20, and the correlation between height and the lateral cephalometric parameters was tested by Karl Pearson correlation coefficient, then the linear regression equations were derived to estimate the height from each lateral cephalometric parameter independently, i.e.: $\mathrm{Y}=\mathrm{A}+\mathrm{B}(\mathrm{X})$. Results: Moderate significant correlation was observed between height and all lateral cephalometric parameters $(p=0.000) \&$ $(\mathrm{R}=.368$ - .521). The linear regression equation using formula $\mathrm{Y}=\mathrm{a}+\mathrm{bX}$ was obtained for each parameter.

Conclusion: This study concludes: all lateral cephalometric parameters tested in this study can be used as an additional tools aid to estimate stature in Syrian population when the bony remains are complete, and a basic tools aid to estimate the stature when there are incomplete bony remains contains only the skull \& mandible bones.
\end{abstract}

Keywords: Stature Estimation; Cephalometric Parameter; Identification; Dentalforensic Anthropology.

\section{Introduction}

The identification of victims is a top priority in the case of traffic accidents, fires, aircraft crashes and major disasters. Also, the importance of identification appears in countries affected by armed conflict, where the war leaves many dead, victims and mass graves $[1,2]$.

The methods of identification of victims differ depending on the physical data remaining at the place of death, which are affected by the physical condition of the victim after death and the time elapsed of death, which will change many of the basic features.

One of the distinguishing features of individuals is height, so it is one of the main variables that contribute to the identification of persons and unidentified bodies [3].

The height is defined as the vertical distance between the top of the head and the bottom of the feet of the person standing bare-

*Corresponding Author:

Ghaith Sahtout,

Ghaith Sahtout, Department of Orthodontics, Faculty of Dental medicine, Damascus University, Syria.

Tel: 00963992635566

Email Id: gsahtout@gmail.com

Received: February 08, 2021

Accepted: February 28, 2021

Published: March 04, 202

Citation: Ghaith Sahtout, Khalid Joma, Mahmoud Abdul-Hak, Majid A Abo Fakher. Stature Estimation By Four Lateral Cephalometric Parameters: Study From A Sample Of Syrian Population. Int J Dentistry Oral Sci. 2021;08(03):1861-1864. doi: http://dx.doi.org/10.19070/2377-8075-21000369

Copyright: Ghaith Sahtout ${ }^{\circ}$ 2021. This is an open-access article distributed under the terms of the Creative Commons Attribution License, which permits unrestricted use, distribution and reproduction in any medium, provided the original author and source are credited. 
foot and head position so that the Frank-furt plane is parallel to the horizon [4].

The height of the human body is proportional to the different parts of the body, which has enabled many forensic researchers to use various parts of the body as indices to help determine height [5].

The height of people is determined using many anthropological variables, such as long bones - femur, calf, humerus, where there is a strong correlation between the height of the person and these variables, but the use of these bones in cases of fragmentation and explosions becomes limited, while the skull, jaws and teeth have good resistance to harsh conditions, and remain for a long time without significant change in their dimensions, making them important factors that may be used as sensors in determining the height in people [6].

\section{The Aim Of The Study}

This study was conducted to evaluate the possibility of using four parameters related to facial and mandible dimensions taken from the lateral cephalometric image as indices for estimating height in the sample of Syrian population.

\section{Materials and Methods}

\section{Place of work:}

This research was conducted in the Department of Orthodontics, Faculty of Dental medicine, Damascus University, Syria.

The researcher explained to all members of the sample about the importance of the research and its objectives and the way it was carried out. Volunteers were accepted on their own initiative only.

\section{Criteria For Admission To Research}

The research members were selected to meet the following criteria:

Healthy person.

Not suffer from any syndrome, evolutionary or genetic disorder (endocrinal - metabolic - developmental) or any chronic diseases (prolonged illness).

Not subject to any orthodontic or orthognathic treatment.

Not subject to any surgical treatment of skull and jaws.

The study was conducted on 150 persons (70 males and 80 females) of the reviewers of the Department of Orthodontics, Faculty of Dental medicine, Damascus University.

The ages range from 18 to 25 years.

\section{Practical Actions}

The height of all the members of the sample was measured in barefoot position and head position so that the Frank-furt plane is parallel to the horizon.

The lateral cephalometric images were obtained from the patients' review files of the Orthodontics Department.

The landmarks used in this study were located by an orthodontist and confirmed by two other orthodontists, the landmarks are detailed as follows:

Nasion: The most anterior point of the front nasal suture.

Menton: The lowest point on thesymphysial outline of the chin.

ANS: The most anterior point of the sharp bony process of the maxilla.

Pogonion: The most prominent point on the front edge of the chin.

Gonion: The most downward and lower point on the lower jaw angle.

Condylion: The point of the jaw is placed on the top posterior part of the condyle.

\section{The Following Dimensions Were Measured:}

\section{Facial Dimensions:}

Total Facial Height: The straight line between Nasion and Menton $(\mathrm{N}-\mathrm{M})$.

Upper Facial Height: The straight line between Nasion and ANS (N - ANS).

\section{Mandible dimensions:}

Ramus length: The straight line between Condylion and Gonion (CO - GO).

Mandibular Body length: The straight line between Gonion and Pogonion (GO - POG).

The magnification ratio in each image of the cephalometric is determined in order to obtain the real dimensions.

Measurements were made on the cephalometric images usingthe Digital Vernier Caliperof the company (Mitutoyo - Japan) with a $\pm 0.01 \mathrm{~mm}$ error.

All measurements were performed by a single observer to avoid the inter-observer error, and each measurement was repeated three times and the average was used to minimize the intra-observer error.

50 patients were randomly selected to repeat all measurements after 1 month from the first meeting to calculate the intraclass correlation coefficient (ICC), and the values of the (ICC) were (0.89 - 0.94) for all parameters.

The data was dumped in an Excel 2013 file, and then statistically processedusing SPSS version 20, and the correlation between 
height and the lateral cephalometric parameters was tested by Karl Pearson correlation coefficient, then the linear regression equations were derived to estimate the height from each lateral cephalometric parameter independently, i.e.: $\mathrm{Y}=\mathrm{a}+\mathrm{b}(\mathrm{X})$, where $y$ : the predicted height of an individual, a: the constant, b: the regression coefficient, $\mathrm{X}$ the value of the lateral cephalometric parameter.

\section{Results}

The descriptive statistics of the height and the lateral cephalometric parameters such as (mean - maximum - minimum - standard deviation) have shown in the table number 1.

The table 2 shows that all lateral cephalometric parameters were moderately correlated with the height of the individual (.368 $.521)$, and this correlation were statistically significant for each parameter $(\mathrm{p}=.000)$.

The lowest SEE value with highest $\mathrm{R}$ value was between the height and the height of the ramus, and the highest SEE value with lowest $\mathrm{R}$ value was between the height and the mandible body length $>$.

\section{Discussion}

Forensic Dentistry is a branch of forensic medicine and is an integral part of it. It seeks to improve the methods of identifying people, and places the unique qualities of the skull and teeth in the service of forensic objectives, so that forensic dentistry becomes more useful for public forensic and judicial investigations associated with it $[7,8]$.

The height of the stature is one of the most important variables that forensic specialists rely on to identify people, a task that may be very difficult in cases where the bodies are severely dispersed, where they have long been dead, and it becomes more difficult to determine the height of the people in case The loss of many parts of the skeletons of bodies, which is common in long-term armed conflicts, which has been happening in Syria for 8 years.

Different geographical regions and societies differ from each other in terms of characteristics of different parts of the human body, and these differences must be taken into consideration in attempts to find special recognition indices for people living in a particular geographical region where these indices are more accurate and reliable than the indices that did not take these differences in to consideration [9]. According to our information, the current study is the first academic study conducted on a sample of Syrian population, trying to find the relation between height in the human and some variables that relate to the dimensions of skull and mandible.

DNA is the most reliable method of identifying victims [10], but it is very expensive and takes a long time to be completed. This limits its usefulness, especially in cases of long-term wars and the existence of many mass graves. What distinguishes the current study is that it is trying to find ways to identify people in Syrian population so that it is easy to implement and their results are quick and cost-effective.

The present study confirms the presence of moderate correlation between height and all parameters related to the face and jaws taken from the lateral cephalometric images, and the value of the highest correlation is between the height and the height of the ramus $(\mathrm{R}=.521)$, and the lowest correlation value was between the height and mandibular body length $(\mathrm{R}=.368)$. This correlation can be explained by the fact that the growth of the skull and the jaws is related to the autologous genes, which leads to the belief that there is a link between the dimensions of the skull and the jaws and other parts of the body.

The results of this study were consistent with the results of the study [11], which was conducted on a sample of the Sudanese Arab society. It included 240 people (120 males and 120 females) between the ages of 18-25 years. The correlation of height with 15 variables was studied on the facial cephalometric images. The results showed a low to moderate correlation between most vari-

Table 1. Minimum, Maximum, Mean, and the standard deviation of each parameter.

\begin{tabular}{|c|c|c|c|c|c|}
\hline parameter & $\mathbf{N}$ & Mean & SD & MIN & MAX \\
\hline$(\mathrm{N}-\mathrm{M})$ & 150 & $116.12 \mathrm{~mm}$ & 8.92 & 94.69 & 144.98 \\
\hline$(\mathrm{M}-\mathrm{ANS})$ & 150 & $51.32 \mathrm{~mm}$ & 4.27 & 41.39 & 66.79 \\
\hline$(\mathrm{CO}-\mathrm{GO})$ & 150 & $55.92 \mathrm{~mm}$ & 5.58 & 43.34 & 73.52 \\
\hline$(\mathrm{GO}-\mathrm{POG})$ & 150 & $73.34 \mathrm{~mm}$ & 6.04 & 58.78 & 90.64 \\
\hline Height & 150 & $164 \mathrm{~cm}$ & 9 & 146 & 186 \\
\hline
\end{tabular}

Table 2. correlation coefficient, $\mathrm{p}$ - value, regression equation, and the standard error of the estimate between the height and each parameter.

\begin{tabular}{|c|c|c|c|c|}
\hline SEE & Regression equation & $\mathbf{P}$ - value & $\mathbf{R}$ & parameter \\
\hline 8.233 & $\mathrm{Y}=103.074+.527 \mathrm{X}$ & 0 & 0.497 & $(\mathrm{~N}-\mathrm{M})$ \\
\hline 8.703 & $\mathrm{Y}=118.935+.882 \mathrm{X}$ & 0 & 0.398 & $(\mathrm{~N}-\mathrm{ANS})$ \\
\hline 8.098 & $\mathrm{Y}=114.865+.883 \mathrm{X}$ & 0 & 0.521 & $(\mathrm{CO}-\mathrm{GO})$ \\
\hline 8.822 & $\mathrm{Y}=121.965+.576 \mathrm{X}$ & 0 & 0.368 & $(\mathrm{GO}-\mathrm{POG})$ \\
\hline
\end{tabular}

SEE: standard error of the estimate 
ables. The correlation between height and total facial height $(\mathrm{R}$ $=.207$ ), while the correlation between height and upper facial height $(\mathrm{R}=.355)$ without any significant differences Between the gender-related correlation values, which are close to the results of the present study and which did not separate gender in relation to correlation values.

The results of the present study also coincided with the results of the [12] Gonzalez-Colmenares and his colleagues' study conducted on a sample of Colombian society. The study included 70 people (54 males and 16 females) to study the predictability of height in people using 10 variants taken from the lateral cephalometric images, and the results of the study showed that the value of the correlation between height and the total facial height and upper facial height were $(\mathrm{R}=.478)$ and $(\mathrm{R}=.272)$ on the sequence for males. These results are close to the results of the current study, where the correlation value of the height with the total facial height and the upper facial height $(\mathrm{R}=.497)$ and $(\mathrm{R}=$ $.398)$ on the sequence, but the correlation value of females in the Colombian community study was negative $(\mathrm{R}=$-.066) for the upper facial height and weak $(R=.202)$ for total facial height. These results differs from the results of current study and this difference can be explained by the fact that the number of females included in the study sample of Colombian population is very small, with only 16 females [12].

The results of the present study were consistent with the results of the (Krishan 2008) [13] study on a sample of northern India consisting of 996 males only and between the ages of 18-30 years, to study the correlation of height with five variables taken from the facial cephalometric images. The correlation of height with total facial height $(\mathrm{R}=.455)$ was very close to the results of the present study, where the correlation value was $(\mathrm{R}=.497)$.

Although Many studies confirm the superiority of long bones on other bones in the process of estimating the height in humans, but skull and mandible bones have to be used to improve the accuracy of the estimated height especially when the bony remains are containing the whole skeleton, but in the presence of bone remains that contain only the skull and mandible bones, it is possible to use equations that link the height with the various dimensions of the skull and mandible [14] which is confirmed by the current study as well.

\section{Conclusion}

The findings of this study conclude that there is an association between the stature and the indices that are related to the dimen- sions of the skull and the mandible. The upper facial height, the total facial height, the ramus height and the mandibular body length can be used as an additional tools aid to estimate stature in Syrian population when the bony remains are complete, and a basic tools aid to estimate the stature when there are incomplete bony remains.

\section{References}

[1]. Anita P, Madankumar PD, Sivasamy S, Balan IN. Validity of Carrea's index in stature estimation among two racial populations in India. J Forensic Dent Sci. 2016 May-Aug;8(2):110. PubmedPMID: 27555731.

[2]. Kanthem RK, Guttikonda VR, Yeluri S, Kumari G. Sex determination using maxillary sinus. J Forensic Dent Sci. 2015 May-Aug;7(2):163-7. PubmedPMID: 26005308.

[3]. Tumram NK, Parchake SB, Bardale RV, Dixit PG. Estimation of height from the length of the sternum in an adult Indian population. Med Sci Law. 2016 Jan;56(1):46-52. PubmedPMID: 26209632.

[4]. Brits D, Manger PR, Bidmos MA. Assessing the use of the anatomical method for the estimation of sub-adult stature in Black South Africans. Forensic Sci Int. 2018 Feb;283:221.e1-221.e9. Pubmed PMID: 29258721.

[5]. Raxter MH, Auerbach BM, Ruff CB. Revision of the Fully technique for estimating statures. Am J PhysAnthropol. 2006 Jul;130(3):374-84. Pubmed PMID: 16425177.

[6]. Kyllonen KM, Simmons-Ehrhardt T, Monson KL. Stature estimation using measurements of the cranium for populations in the United States. Forensic Sci Int. 2017 Dec;281:184.e1-184.e9. Pubmed PMID: 29129342.

[7]. Krishan K, Kanchan T, Garg AK. Dental Evidence in Forensic Identification - An Overview, Methodology and Present Status. Open Dent J. 2015 Jul 31;9:250-6. PubmedPMID: 26312096.

[8]. Liu F, Dang YH. Research Progress on Forensic Dentistry. Fayixuezazhi. 2017 Apr 25;33(2):175-80.

[9]. Cattaneo C. Forensic anthropology: developments of a classical discipline in the new millennium. Forensic Sci Int. 2007 Jan 17;165(2-3):185-93. Pubmed PMID: 16843626.

[10]. NathaN MD, SaKthi DS. Dentistry and mass disaster-A review. Journal of clinical and diagnostic research: JCDR. 2014 Jul;8(7):ZE01.

[11]. Ahmed AA, Taha S. Cephalo-facial analysis to estimate stature in a Sudanese population. Leg Med (Tokyo). 2016 May;20:80-6. Pubmed PMID: 27161929.

[12]. González-Colmenares G, Medina CS, Báez LC. Estimation of stature by cephalometric facial dimensions in skeletonized bodies: study from a sample modern Colombians skeletal remains. Forensic Sci Int. 2016 Jan;258:101. e1-6. PubmedPMID: 26631845.

[13]. Krishan K. Estimation of stature from cephalo-facial anthropometry in north Indian population. Forensic Sci Int. 2008 Oct 25;181(1-3):52.e1-6. Pubmed PMID: 18799276.

[14]. Patil KR, Mody RN. Determination of sex by discriminant function analysis and stature by regression analysis: a lateral cephalometric study. Forensic Sci Int. 2005 Jan 29;147(2-3):175-80. PubmedPMID: 15567623. 